\title{
Biocontrol of Citrus Canker Disease Caused by Xanthomonas citri subsp. citri Using an Endophytic Bacillus thuringiensis
}

\author{
Md. Nurul Islam ${ }^{1 \dagger}$, Md. Sarafat Ali ${ }^{1 \dagger}$, Seong-Jin Choi ${ }^{2}$, Jae-Wook Hyun ${ }^{3}$, and Kwang-Hyun Baek ${ }^{1 *}$ \\ ${ }^{I}$ Department of Biotechnology, Yeungnam University, Gyeongsan 38541, Korea \\ ${ }^{2}$ Department of Biotechnology, Catholic University of Daegu, Gyeongsan 38430, Korea \\ ${ }^{3}$ Citrus Research Station, National Institute of Horticultural and Herbal Science, Rural Development Administration, \\ Seogwipo 63607, Korea
}

(Received on March 20, 2019; Revised on July 5, 2019; Accepted on August 12, 2019)

Citrus canker is a devastating disease of citrus caused by Xanthomonas citri subsp. citri (Xcc). A total of 134 endophytic bacteria were isolated from various gymnospermic and angiospermic plants. They were screened for their antagonistic activities against three wild-type and six streptomycin-resistant $X c c$ strains. TbL-22 and TbL-26, both later identified as Bacillus thuringiensis, inhibited all the wild and resistant Xcc strains. TbL-22 exerted the highest antagonistic activity against $\mathrm{XccW3}$ and $X c c M 6$ with inhibition zones of $20.64 \pm 0.69$ and $19.91 \pm 0.87 \mathrm{~mm}$, respectively. Similarly ethyl acetate extract of TbL-22 showed highest inhibition zones 15.31 \pm 2.08 and $19.37 \pm 3.17 \mathrm{~mm}$ against $X c c \mathrm{~W} 3$ and $X c c \mathrm{M6}$, respectively. TbL-22 reduced canker incidence on infected leaves by $64.05 \%$ relative to positive controls. Scanning electron microscopy revealed that the cell membranes of $X c c$ treated with ethyl acetate extract of TbL-22 were ruptured, lysed, and swollen. B. thuringiensis TbL-22 can effectively and sustainably controls streptomycin-resistant citrus canker.

Keywords : Bacillus thuringiensis, biocontrol, citrus canker, endophytic bacteria

\section{Handling Editor : Sang, Mee Kyung}

\footnotetext{
${ }^{\dagger}$ These authors contributed equally to this work.

*Corresponding author.

Phone) +82-53-810-3029, FAX) +82-53-810-4769

E-mail)khbaek@ynu.ac.kr

(c) This is an Open Access article distributed under the terms of the Creative Commons Attribution Non-Commercial License (http:// creativecommons.org/licenses/by-nc/4.0) which permits unrestricted noncommercial use, distribution, and reproduction in any medium, provided the original work is properly cited.
}

Articles can be freely viewed online at www.ppjonline.org.
Citrus is a genus of flowering plants belonging to the family Rutaceae. It originated in Australia, New Caledonia, and New Guinea (Liu et al., 2012). Citrus fruits provide an ample supply of vitamin $\mathrm{C}$, folic acid, minerals, fiber, and various phytochemicals such as carotenoids, flavonoids, and limonoids which have tremendous health benefit. They contain no fat or cholesterol and have low sodium levels (Paul and Shaha, 2004; Ramful et al., 2010). The production of citrus fruits, however, is threatened by bacterial canker disease (Gottwald et al., 2001). The causative agent is Xanthomonas citri subsp. citri $(X c c)$. Symptoms include leaf spotting, fruit rind blemishing, defoliation, shoot dieback, and fruit drop in favorable environmental conditions conducive to pathogen proliferation (Das, 2003). This disease has a serious economic impact on citrus production worldwide (Jalan et al., 2013). Citrus canker outbreaks occurred in the state of Florida in 1910, 1984, and 1995. Many controlling methods were attempted to control the disease by uprooting and burning all citrus trees known or suspected to be infected with the pathogen (Gottwald et al., 2001).

Integrated management practices can reduce citrus canker incidence by (1) using canker disease-free nursery plants, (2) pruning and burning infected twigs, (3) spraying copper-based bactericides, and (4) developing canker-resistant varieties (Das and Singh, 1999, 2001). The integrated application of copper oxychloride $(0.3 \%)$, streptocycline (100 ppm), and neem cake suspension on infected twigs was very effective in controlling the disease (Das and Singh, 2000). Since 1955, streptomycin has been used as the main antibiotic to control various bacterial diseases of Citrus spp. as well as fire blight, soft rot, bacterial spot, and wildfire diseases on other crops (McManus et al., 2002). Nevertheless, pathogen resistance to streptomycin has de- 
veloped due to its prolonged and excessive use (Carter et al., 2000; Hyun et al., 2012). In a recent study, $72 \%$ of the $X c c$ strains isolated from Jeju Island, Republic of Korea were found to be resistant to streptomycin (Hyun et al., 2012).

The cultivation of citrus varieties resistant to citrus canker is an effective and eco-friendly means of controlling the disease. The development of disease-resistant varieties, however, is time-consuming, laborious, and not widely available. Therefore, it is neither practical nor convenient as a citrus canker control method. For sustainable citrus production, more effective and sustainable techniques are required to control citrus canker.

Endophytes are important components in plant-microbe ecosystems (Li et al., 2012) and may serve as environmentally sustainable resources for citrus canker control. Endophytic microorganisms are bacteria or fungi that colonize the internal host tissues in high numbers but do not harm the host or induce plant disease symptoms (Quispel, 1992). Endophytic bacteria (EB) are endosymbiotic microorganisms that colonize the same ecological niches as phytopathogens, so they can function as biocontrol agents and coexist safely with plant tissues (Berg et al., 2005; Kloepper and Beauchamp, 1992). The application of EB as biocontrol agents enhances disease resistance (Van Loon et al., 1998) and provides a safe alternative to chemical control products (Backman and Sikora, 2008). Several EB used as biocontrol agents have been isolated from various plants, e.g., Burkholderia cepacia from citrus (Tan et al., 2007), Aureobacterium saperdae, Bacillus pumilus, Phyllobacterium rubiacearum, and Pseudomonas putida from cotton (Chen et al., 1995), and Enterobacter cloacae from rice (Yang et al., 2001).

In this study, EB isolated from different gymnosperm and angiosperm tissues were evaluated for their efficacy against citrus canker disease. Antibacterial efficacy was tested using three wild-type and six streptomycin-resistant mutant Xcc strains. The objectives of this research were to (1) screen for effective EB against Xcc strains and (2) determine the efficacies of the best EB able to control citrus canker through both in vitro and in vivo assays.

\section{Materials and Methods}

Collection of plant materials and isolation of EB. Various gymnosperms and angiosperms, including Metasequoia glyptostroboides, Ginkgo biloba, Taxus brevifolia, Pinus densiflora, Salix babylonica, and Salix chaenomeloides were sampled at Yeungnam University, Gyeongsan, Republic of Korea in October 2014. Leaves, fruit, seeds, and cones (Table 1) were collected, placed in plastic bags, and brought to the laboratory for EB isolation.

EB were isolated according to standard procedures (De Oliveira Costa et al., 2012) with minor modifications. Plant parts were washed under running tap water. Visibly injured organs were discarded. The samples were dried and weighed on a digital balance. Tissues were sterilized by exposure to $70 \% \mathrm{v} / \mathrm{v}$ alcohol for $60 \mathrm{~s}, 2 \%$ sodium hypochlorite for $180 \mathrm{~s}$, and $100 \%$ ethanol for $30 \mathrm{~s}$. The tissues were then rinsed several times with sterile distilled water (SDW) and dried with sterile filter papers. The plant parts were then ground with sterile $3 \mathrm{ml} / \mathrm{g}$ of aqueous $\mathrm{NaCl}$ solution $(0.9 \% \mathrm{w} / \mathrm{v})$ using a sterile mortar and pestle. The tissue extracts were incubated at $28^{\circ} \mathrm{C}$ for $3 \mathrm{~h}$ to release all of the EB.

The tissue extracts were diluted to $10^{-1}$ and $10^{-2}$ with sterile $\mathrm{NaCl}$ solution. They were then applied with a stainless steel spreader onto Petri dishes containing 25\% yeast extract, nutrient broth and agar (YNA), 25\% nutrient agar, de Man, Rogosa and Sharpe agar, or Luria-Bertani agar media to obtain single bacterial colonies. The plates were incubated for up to 15 days at $28^{\circ} \mathrm{C}$. All colonies were counted and reported as the number of colony-forming units per gram fresh tissue [cfu/g fresh weight (FW)]. Single colony isolation was repeated at least three times to obtain pure EB isolates. Colony form, margin, color, and elevation were recorded. The selected EB were cultured in various media broths and stored in $50 \%$ glycerol at $-80^{\circ} \mathrm{C}$ until use.

The isolated EB were identified with 16S rRNA gene sequencing. The sequencing data, alignment, and phylogenetic trees were analyzed by Molecular Evolutionary Genetics Analysis (MEGA) 6 software version 6.0. The phylogenetic trees were also analyzed by the neighbor-joining method (Susilowati et al., 2015; Tamura et al., 2013).

Antagonistic assay of EB against citrus canker pathogen $X c c$. Nine $X c c$ strains, including three wild-type and six streptomycin-resistant mutants (Hyun et al., 2012) were used in this study. The wild-type (XccW1 [Xcc 19-18], $X c c \mathrm{~W} 2$ [Xcc 10-5], and XccW3 [Xcc 53-4]) and streptomycin-resistant mutant (XccM4 [Xcc 27-9], XccM5 [Xcc 8-4], XccM6 [Xcc 57-2], XccM7 [Xcc 57-5], XccM8 [Xcc 2713], and XccM9 [Xcc 27-12]) strains were kindly provided by Dr. Hyun of the Citrus Research Station, National Institute of Horticultural and Herbal Science, Rural Development Administration, Jeju, Korea. The wild-type Xcc were grown in yeast extract-nutrient broth (YNB) medium. The streptomycin-resistant $X c c$ strains were incubated in YNB supplemented with $50 \mathrm{mg} / \mathrm{ml}$ streptomycin. All Xcc were stored in $50 \%$ glycerol at $-80^{\circ} \mathrm{C}$ until use. 
The EB isolates were screened for antagonistic activity against the nine strains of $X c c$ following standard procedures (Roh et al., 2009) with minor modifications. Screening was performed by culturing $134 \mathrm{~EB}$ isolates in 96-well plates with $10 \mu \mathrm{l}$ individual bacterial strain grown in YNB and the plates were incubated for $36 \mathrm{~h}$ at $28^{\circ} \mathrm{C}$. Then the cultured bacteria were again grown on square plates (size as $127.94 \times 85.50 \times 16.25 \mathrm{~mm}$, SPL Life Sciences Co., Ltd., Pocheon, Korea) using $25 \%$ YNA (1.5\% agar) media following incubation for $36 \mathrm{~h}$ at $28^{\circ} \mathrm{C}$. The $\mathrm{EB}$ were then killed by placing $1 \mathrm{ml}$ chloroform on the square plate lids and inverting the plates for $15 \mathrm{~min}$. The lids were then removed and the plates were left to stand for $20 \mathrm{~min}$ to vent any chloroform residue, then the plates were treated with UV light for $15 \mathrm{~min}$ to kill the bacteria completely. Simultaneously, $30 \mu 1$ aliquots of $X c c$ cultures that had been grown overnight in $\mathrm{YNB}$ media at $28^{\circ} \mathrm{C}$ were suspended in $10-\mathrm{ml}$ fresh $\mathrm{YNB}$ media $(0.75 \%$ agar $)$ at $55^{\circ} \mathrm{C}$, mixed gently, then poured slowly and uniformly on the square plates. After the agar solidified, all the plates were sealed and incubated at $28^{\circ} \mathrm{C}$ for $24 \mathrm{~h}$. Inhibition zone diameters were measured using an electronic digital caliper (M500-182M, Hando, Cheonan, Korea) with a $1 / 100 \mathrm{~mm}$ precision.

Further analysis for the antagonistic activity was done using TbL-22 (B. thuringiensis) and TbL-26 (B. thuringiensis) as the isolates with the highest antagonistic activity along with TbS-8 (B. altitudinis) and TbL-19 (B. altitudi$n i s)$ as the isolates of another Bacillus species against all of Xcc strains. The above-described method was used the same way using all $X c c$ strains and using Petri dish $(90 \mathrm{~mm}$ diameter) instead of square plates.

Antagonistic activity of the extracted EB against Xcc. After being sub-cultured on YNA plates for $24 \mathrm{~h}$, single colonies of the antagonistic EB were added to $200 \mathrm{ml}$ YNB in 1-liter Erlenmeyer flasks with continuous shaking at $180 \mathrm{rpm}$ at $28^{\circ} \mathrm{C}$ for $48 \mathrm{~h}$. The culture broths were centrifuged at $3,500 \mathrm{rpm}$ for $15 \mathrm{~min}$ at $4^{\circ} \mathrm{C}$. The supernatant was collected, mixed with equal volumes of ethyl acetate and incubated overnight. Ethyl acetate was selected for the metabolite extraction process for its low boiling point and moderate polarity. Simultaneously, the bacterial pellets were suspended in $20 \mathrm{ml}$ methanol, placed in a sonicating bath (WUC-A03H, Daihan Scientific Co., Wonju, Korea) for $15 \mathrm{~min}$ to break the cells and incubated overnight. The ethyl acetate layer was then collected in a separating funnel. The methanol extract was separated from the bacterial debris by centrifugation at $3,500 \mathrm{rpm}$ for $15 \mathrm{~min}$ at $4^{\circ} \mathrm{C}$. Both extracts were dried at $50^{\circ} \mathrm{C}$ in a rotary evaporator (A1000S, EYELA, Tokyo, Japan). The dried extracts were then removed from the evaporation flask, dissolved in 2 $\mathrm{ml}$ methanol, and air-dried in tubular glass vials. The ethyl acetate extract was measured and dissolved in 5\% dimethyl sulfoxide (DMSO) in methanol to make $0.1 \mathrm{~g} / \mathrm{ml}$. Total 50 $\mu l$ aliquots of this dilution were used to the well diffusion assay. The antagonistic activities of the EB against the Xcc strains were determined by measuring the inhibition zone diameters.

Determination of the minimum inhibitory concentration (MIC) and the minimum bactericidal concentration (MBC). The MIC and MBC of the ethyl acetate extract of TbL-22 against $X c c$ were determined by the twofold dilution method (Patra et al., 2015) with minor modifications. Five percent DMSO was used both as a control and a solvent to homogenize the ethyl acetate extract for the MIC and MBC tests. Various dilutions of the ethyl acetate extract of TbL-22 in YNB media were prepared. The lowest concentration of TbL-22 at which there was zero visible $X c c$ growth was taken to be the MIC and was recorded in $\mathrm{mg} / \mathrm{ml}$. The MIC and the next higher concentration were selected, spread on YNA plates and incubated at $28^{\circ} \mathrm{C}$ for $24 \mathrm{~h}$. The lowest concentration of TbL-22 at which no pathogenic bacteria grew on the $25 \%$ YNA plates was considered the MBC and was expressed in $\mathrm{mg} / \mathrm{ml}$.

Analysis using scanning electron microscopy (SEM). The effects of the ethyl acetate extract of TbL-22 on Xcc cell morphology were determined by SEM analysis. Both the 5\% DMSO control and the samples treated with the ethyl acetate extract of TbL-22 were applied to the four Xcc strains and observed under SEM using a slightly modified version of the procedure described by Bajpai et al. (2009). The four different $X c c$ strains used for SEM analysis were $X c c \mathrm{~W} 1, X c c \mathrm{M} 4, X c c \mathrm{M} 6$, and $X c c \mathrm{M} 8$, which were selected based on their genotypic classification. Overnight bacterial culture samples were washed gently with $0.05 \mathrm{M}$ phosphate buffer solution ( $\mathrm{pH} 7.4$ ) and fixed with $2.5 \% \mathrm{v} / \mathrm{v}$ glutaraldehyde in SDW. The specimens were dehydrated with sequential exposures to ethanol ranging from 50 to $100 \%$. The ethanol was then replaced with tert-butyl alcohol. The specimens were sputter-coated with platinum in an ion coater for $120 \mathrm{~s}$ then examined under an SEM (S-4100, Hitachi, Tokyo, Japan).

Biocontrol efficacy of the antagonistic EB. Pathogenic wild-type $X c c \mathrm{~W} 2$ were grown at $28^{\circ} \mathrm{C}$ in YNB media. Overnight bacterial cell cultures were harvested at $4^{\circ} \mathrm{C}$, centrifuged at 3,500 rpm for $15 \mathrm{~min}$, and suspended in SDW to make a concentration of $0.4 \mathrm{OD}_{600 \mathrm{~mm}}$ determined 
by spectrophotometer (ASP-3700, ACTGene, Piscataway, NJ, USA). For the detached leaf assay (Brown and Soepena, 1994), fully expanded immature (4-week-old) leaves were excised from Hwanggeum hyang, a highly cankersusceptible cultivar generated from the cross between Citrus unshiu $\times C$. sinensis and C. unshius. The leaves were infiltrated with a $0.1 \mathrm{ml}$ bacterial suspension using a $1-\mathrm{ml}$ needleless syringe. The bacterial suspensions were prepared by mixing $0.4 \mathrm{OD}_{600 \mathrm{~nm}} X c c \mathrm{~W} 2$ either with 0.4 $\mathrm{OD}_{600 \mathrm{~nm}}$ EB suspension or with SDW. The infiltrated leaves were placed on three layers of sterile tissue paper moistened with SDW in a humid box and incubated in a growth chamber at $28^{\circ} \mathrm{C}$. The infiltrated leaves were photographed, and any canker lesions that developed were measured 7 days post-infiltration (dpi) (Martínez-Medina et al., 2013).

Pathogenicity test of the isolated EB. To determine whether TbL-22 and TbL-26 could cause disease in citrus plants, bacterial suspensions at $0.4 \mathrm{OD}_{600 \mathrm{~nm}}$ concentration were infiltrated into Hwanggeum hyang leaves as described by Brown and Soepena (1994). The pathogenic bacterium $X c c \mathrm{~W} 2$ and SDW were used as a positive and negative control, respectively. Citrus canker disease symptoms were assessed for up to $7 \mathrm{dpi}$.
Table 1. Isolation of endophytic bacteria from different gymnosperms and angiosperms

\begin{tabular}{llcc}
\hline $\begin{array}{c}\text { Plant } \\
\text { species }\end{array}$ & Tissues & $\begin{array}{c}\text { No. } \\
\text { of isolates }\end{array}$ & $\begin{array}{c}\text { cfu/g of } \\
\text { fresh tissue }\end{array}$ \\
\hline $\begin{array}{c}\text { Metasequoia } \\
\text { glyptostroboides }\end{array}$ & Leaves & 4 & $3.3 \times 10^{4}$ \\
Ginkgo biloba & Leaves & 4 & $1.2 \times 10^{3}$ \\
& Fruits & 39 & $6.0 \times 10^{4}$ \\
Taxus brevifolia & Leaves & 23 & $8.6 \times 10^{4}$ \\
& Seeds & 8 & $7.2 \times 10^{3}$ \\
Pinus densiflora & Fruits & 10 & $1.8 \times 10^{2}$ \\
Salix babylonica & Leaves & 2 & $9.6 \times 10^{3}$ \\
Salix chaenomeloides & Leaves & 24 & $1.5 \times 10^{5}$ \\
Total & & 9 & $5.9 \times 10^{4}$ \\
cfu, colony-forming units. & 134 & \\
\hline
\end{tabular}

cfu, colony-forming units.

Statistical analysis. All data were expressed as the mean \pm standard deviation by measuring four independent replicates per experiment. Statistical analysis of the results was conducted by one-way ANOVA followed by the Duncan's multiple range test at $P<0.05$ using SAS version 9.4 (SAS Institute Inc., Cary, NC, USA).

Table 2. Screening and identification of antibacterial activity of endophytic bacteria isolated from gymnosperms and angiosperms against $X c c \mathrm{~W} 1$

\begin{tabular}{|c|c|c|c|c|}
\hline Isolate & Species & $\begin{array}{c}\text { Coverage } \\
(\%)\end{array}$ & $\begin{array}{c}\text { Max. } \\
\text { identity }(\%)\end{array}$ & $\begin{array}{c}\text { Antibacterial } \\
\text { activity }^{\mathrm{a}}\end{array}$ \\
\hline TbL-6 & Kocuria palustris & 97 & 99 & 18.05 \\
\hline TbL-7 & Moraxella osloensis & 99 & 99 & 18.03 \\
\hline TbS-8 & Bacillus altitudinis & 98 & 99 & 18.15 \\
\hline TbL-9 & Moraxella osloensis & 99 & 99 & 16.79 \\
\hline TbL-11 & Staphylococcus epidermidis & 98 & 99 & 17.30 \\
\hline TbF-18 & Staphylococcus saprophyticus & 99 & 99 & 12.59 \\
\hline TbL-19 & Bacillus altitudinis & 97 & 99 & 17.65 \\
\hline TbF-20 & Dermacoccus profundi & 97 & 99 & 17.39 \\
\hline TbF-21 & Staphylococcus warneri & 97 & 99 & 16.05 \\
\hline TbL-22 & Bacillus thuringiensis & 97 & 99 & 18.68 \\
\hline TbS-23 & Bacillus stratosphericus & 98 & 99 & 18.18 \\
\hline TbL-24 & Bacillus stratosphericus & 83 & 99 & 18.15 \\
\hline TbL-26 & Bacillus thuringiensis & 98 & 100 & 18.52 \\
\hline TbL-31 & Staphylococcus epidermidis & 98 & 99 & 12.73 \\
\hline TbL-34 & Bacillus altitudinis & 97 & 99 & 18.06 \\
\hline $\mathrm{SbL}-44$ & Pseudomonas tremae & 97 & 99 & 18.12 \\
\hline $\mathrm{SbL}-46$ & Pantoea vagans & 94 & 97 & 18.17 \\
\hline $\mathrm{SbL}-50$ & Xanthomonas gardneri & 83 & 99 & 12.38 \\
\hline
\end{tabular}

TbL, Taxus brevifolia leaf; TbS, T. brevifolia seed; TbF, T. brevifolia fleshy part of fruit; SbL, Salix babylonica leaf. ${ }^{a}$ Diameter of inhibition zones of antibacterial activity are expressed in millimeters. 
Table 3. Antagonistic activity of isolated endophytic bacteria against Xanthomonas citri subsp. citri (Xcc)

\begin{tabular}{lcccccccccc}
\hline \multirow{2}{*}{ Isolate } & \multirow{2}{*}{ Species } & \multicolumn{7}{c}{ Xcc (inhibition zone in mm) } \\
\cline { 3 - 9 } & & $X c c \mathrm{~W} 1$ & $X c c \mathrm{~W} 2$ & $X c c \mathrm{~W} 3$ & $X c c \mathrm{M} 4$ & XccM5 & XccM6 & XccM7 & XccM8 & XccM9 \\
\hline \multirow{2}{*}{ TbL-22 } & Bacillus & $15.33 \pm$ & $19.43 \pm$ & $20.64 \pm$ & $19.72 \pm$ & $19.90 \pm$ & $19.91 \pm$ & $19.84 \pm$ & $19.78 \pm$ & $18.44 \pm$ \\
& thuringiensis & $0.42 \mathrm{a}^{\mathrm{b}}$ & $1.27 \mathrm{a}$ & $0.69 \mathrm{a}$ & $0.63 \mathrm{a}$ & $1.01 \mathrm{a}$ & $0.87 \mathrm{a}$ & $0.04 \mathrm{a}$ & $0.55 \mathrm{a}$ & $1.17 \mathrm{a}$ \\
\multirow{2}{*}{ TbL-26 } & Bacillus & $11.65 \pm$ & $15.27 \pm$ & $16.54 \pm$ & $16.96 \pm$ & $15.16 \pm$ & $17.34 \pm$ & $15.89 \pm$ & $16.64 \pm$ & $15.78 \pm$ \\
& thuringiensis & $0.22 \mathrm{~b}$ & $1.22 \mathrm{~b}$ & $1.16 \mathrm{~b}$ & $0.07 \mathrm{~b}$ & $0.79 \mathrm{~b}$ & $0.67 \mathrm{~b}$ & $0.35 \mathrm{~b}$ & $0.21 \mathrm{~b}$ & $0.44 \mathrm{~b}$ \\
\hline
\end{tabular}

${ }^{\mathrm{a}}$ Diameter of inhibition zone $(\mathrm{mm})$ of three independent replicates expressed as the mean \pm standard deviation.

${ }^{b}$ Values with different lower case letters in the same column are significantly different at $P<0.05$ by Duncan's test.

\section{Results}

Isolation and identification of EB. A total of 134 morphologically distinct EB were isolated from M. glyptostrobodies, G. biloba, T. brevifolia, P. densiflora, S. babylonica, and $S$. chaenomeloides. They were obtained from the leaves (73 isolates, $54.48 \%$ ), fruit (49 isolates, $36.57 \%$ ), seeds ( 8 isolates, $5.97 \%$ ), and cones (4 isolates, $2.98 \%$ ) (Table 1). The tissue-specific cell counts (CFU) per gram
FW were in the range of $1.8 \times 10^{2}-6.0 \times 10^{4} \mathrm{cfu} / \mathrm{g}$ in the fruits, $1.8 \times 10^{3}-1.5 \times 10^{5} \mathrm{cfu} / \mathrm{g}$ in the leaves, $7.2 \times 10^{3} \mathrm{cfu} / \mathrm{g}$ in the seeds, and $1.2 \times 10^{3} \mathrm{cfu} / \mathrm{g}$ in the cones (Table 1 ).

Antagonistic activity of $\mathrm{EB}$ against $\mathrm{Xcc}$. In the primary screening, all EB isolates were tested for antagonistic activity against $X c c \mathrm{~W} 1$. Eighteen of the EB efficacious against $X c c \mathrm{~W} 1$ were identified by $16 \mathrm{~S}$ rRNA gene sequencing analysis (Table 2). Among them, TbL-22 and TbL-26 exerted the highest antagonistic activity against all $X c c$, so
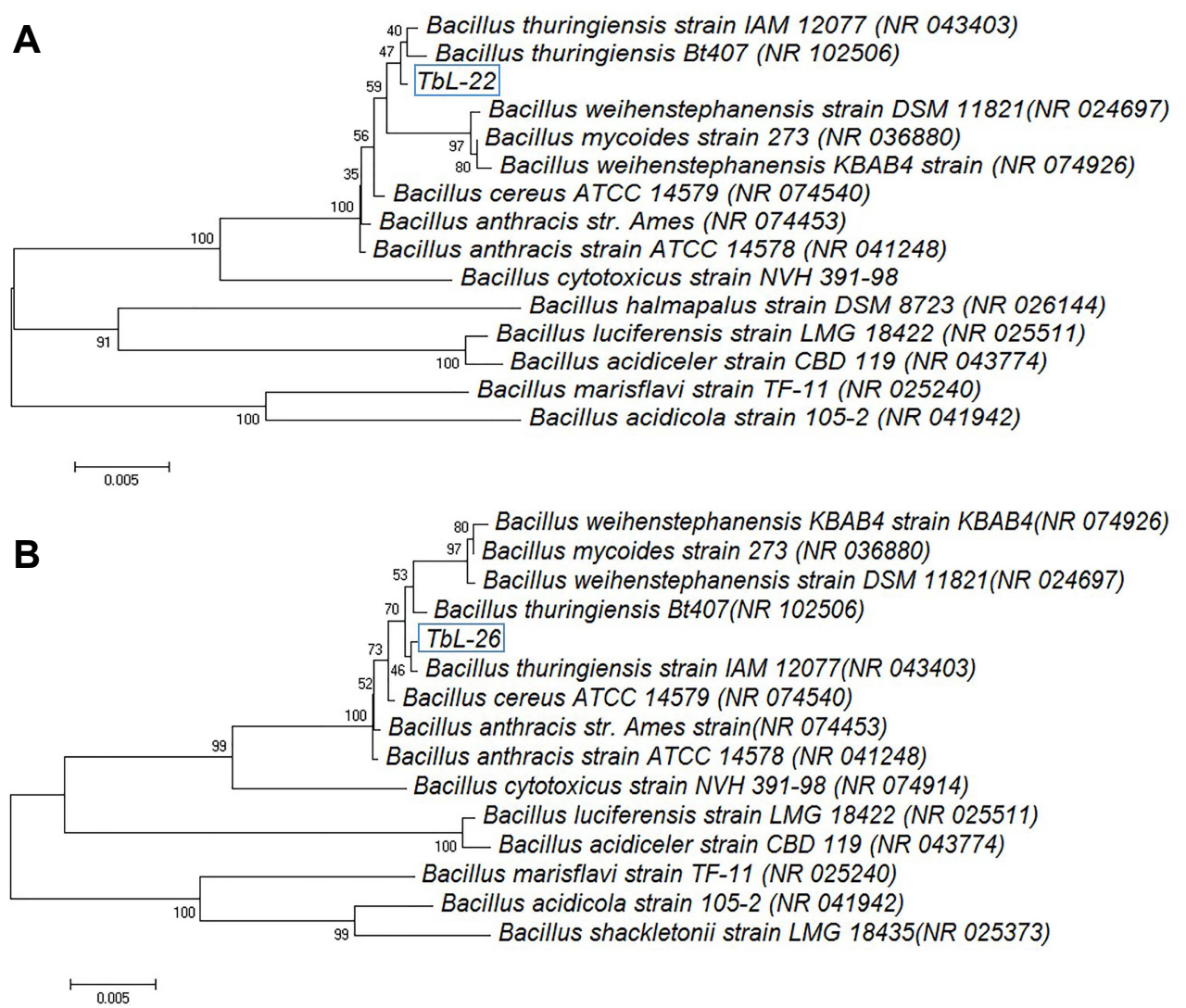

Fig. 1. Neighbor-joining phylogenetic tree based on 16S rRNA gene sequence analyses showing the relationships among the selected strains TbL-22 (A), TbL-26 (B), and the standard strains. Evolutionary distances were computed using the maximum composite likelihood method. The numbers at the nodes are bootstrap values \% (based on 1,000 samples). GenBank accession numbers are shown in parentheses. 


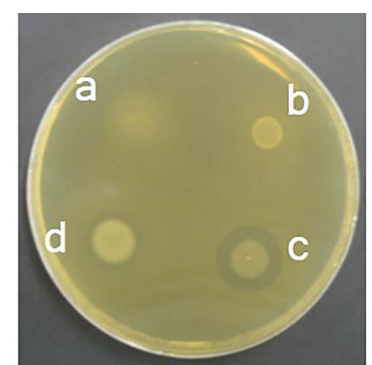

$X c c W 1$

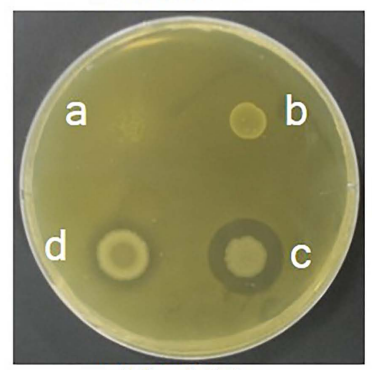

XccM4

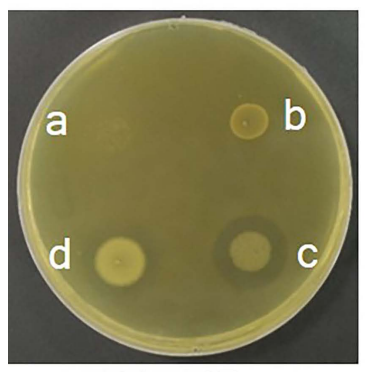

XccM7
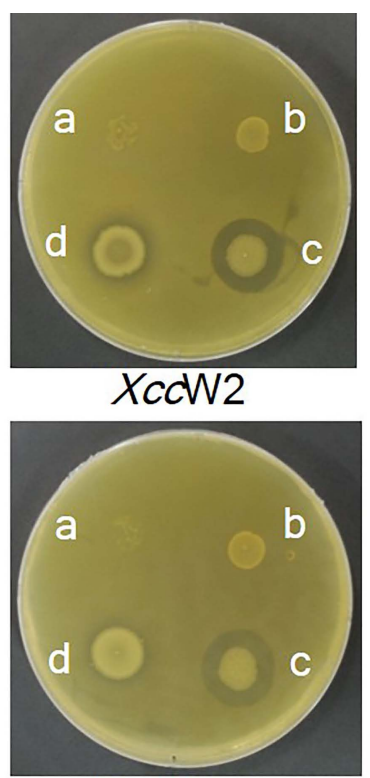

XccM5

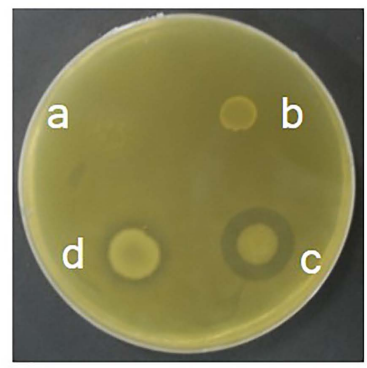

XccM8
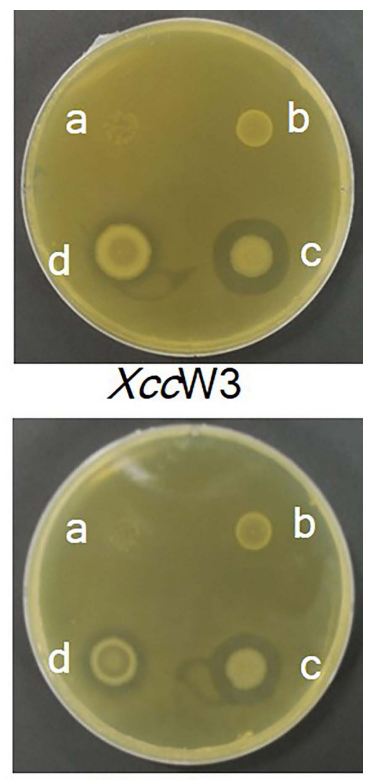

XccM6

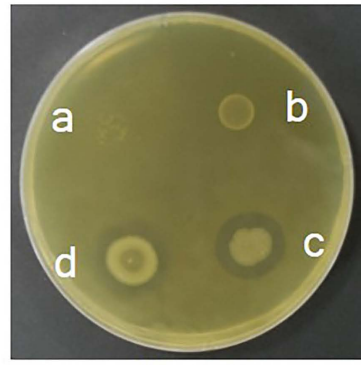

XccM9
Fig. 2. Antagonistic activity of isolated endophytic bacteria against Xanthomonas citri subsp. citri $(X c c \mathrm{~W} 1-X c c \mathrm{~W} 3$ [wild-type strains] and $X c c \mathrm{M} 4-X c c \mathrm{M} 9$ [streptomycin-resistant mutant type strains]). a, TbS-8 (Bacillus altitudinis); b, TbL-19 (B. altitudinis); c, TbL-22 (B. thuringiensis); d, TbL-26 (B. thuringiensis). they were selected for further study (Table 3). Phylogenetic trees were constructed using the $16 \mathrm{~S}$ rRNA sequences of TbL-22 and TbL-26 and those of their closest relatives. The phylogenetic tree analysis revealed that TbL-22 and TbL26 had $99 \%$ and 100\% identity with the 16S rRNA gene sequences of $B$. thuringiensis $\mathrm{Bt} 407$ and B. thuringiensis IAM12077, respectively (Fig. 1A and B).

In Xcc cultures, TbL-22 and TbL-26 exhibited the highest antagonistic activity with inhibition zones of 20.6415.33 and 17.34-11.65 mm, respectively (Table 3, Fig. 2).
TbL-22 had greater activity than TbL-26 against all Xcc. Only the ethyl acetate extract of TbL-22 was antagonistic against all Xcc strains (Table 4, Fig. 3). The extract of TbL-22 exerted the highest antagonistic activity of all, and produced inhibition zones of $15.31 \pm 2.08 \mathrm{~mm}$ and 19.37 $\pm 3.17 \mathrm{~mm}$ against $X c c \mathrm{~W} 3$ and $X c c \mathrm{M} 6$, respectively. The extract of TbL-26 produced inhibition zones of $13.81 \pm 1.05$ $\mathrm{mm}$ and $18.08 \pm 4.69 \mathrm{~mm}$ against $X c c \mathrm{~W} 3$ and $X c c \mathrm{M} 6$, respectively, but had no antagonistic activity against $X c c \mathrm{~W} 2$ (Table 4, Fig. 3).

Table 4. Antagonistic activity of ethyl acetate extract of endophytic bacteria TbL-22 and TbL-26 against Xcc

\begin{tabular}{|c|c|c|c|c|c|c|c|c|c|c|}
\hline \multirow{2}{*}{ Isolate } & \multirow{2}{*}{ Species } & \multicolumn{9}{|c|}{$X c c$ (inhibition zone in $\mathrm{mm}$ ) } \\
\hline & & $X c c \mathrm{~W} 1$ & $X c c \mathrm{~W} 2$ & $X c c \mathrm{~W} 3$ & $X c c \mathrm{M} 4$ & XccM5 & XccM6 & XccM7 & XccM8 & ХccМ9 \\
\hline TbL-22 & Bacillus & 15.24 & 15.07 & 15.31 & 16.31 & 17.16 & 19.37 & 14.32 & 14.26 & 16.81 \\
\hline & thuringiensis & $\pm 1.14 \mathrm{a}^{\mathrm{b}}$ & $\pm 1.09 \mathrm{a}$ & $\pm 0.08 \mathrm{a}$ & $\pm 3.95 \mathrm{a}$ & $\pm 1.30 \mathrm{a}$ & $\pm 3.17 \mathrm{a}$ & $\pm 1.08 \mathrm{a}$ & $\pm 0.46 \mathrm{a}$ & $\pm 3.04 \mathrm{a}$ \\
\hline TbL-26 & $\begin{array}{c}\text { Bacillus } \\
\text { thuringiensis }\end{array}$ & $\begin{array}{r}15.27 \\
\pm 0.09 \mathrm{a}\end{array}$ & - & $\begin{array}{c}13.81 \\
\pm 1.05 \mathrm{a}\end{array}$ & $\begin{array}{c}13.96 \\
\pm 1.39 \mathrm{a}\end{array}$ & $\begin{array}{c}15.54 \\
\pm 3.97 \mathrm{a}\end{array}$ & $\begin{array}{r}18.08 \\
\pm 4.69 \mathrm{a}\end{array}$ & $\begin{array}{c}15.64 \\
\pm 1.92 \mathrm{a}\end{array}$ & $\begin{array}{c}13.44 \\
\pm 0.88 \mathrm{a}\end{array}$ & $\begin{array}{c}12.56 \\
\pm 0.20 \mathrm{a}\end{array}$ \\
\hline
\end{tabular}

Xcc, Xanthomonas citri subsp. citri; -, no inhibition zone.

${ }^{a}$ Diameter of inhibition zone in $(\mathrm{mm})$ of three independent replicates expressed as the mean \pm standard deviation.

balues with different lower case letters in the same column are significantly different at $P<0.05$ by Duncan's test. 


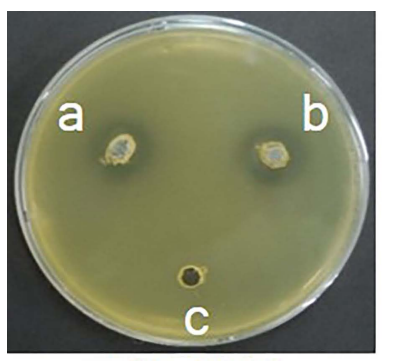

XcdW1

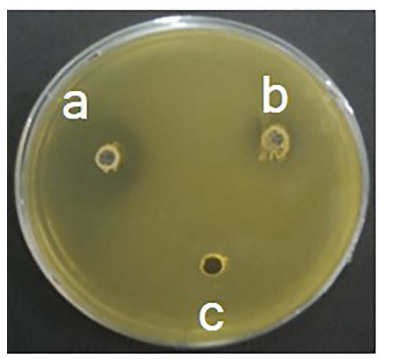

XccM4

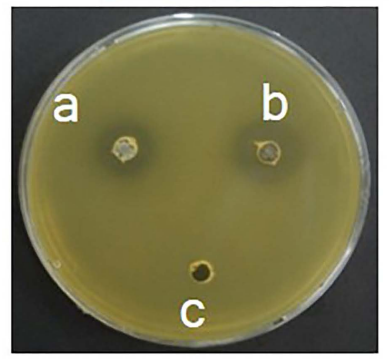

XccM7

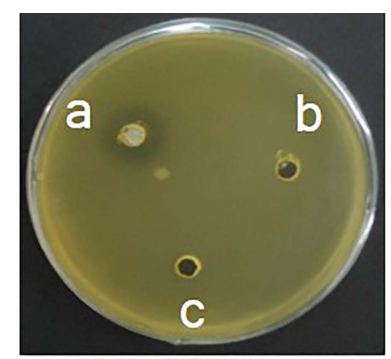

XccW2

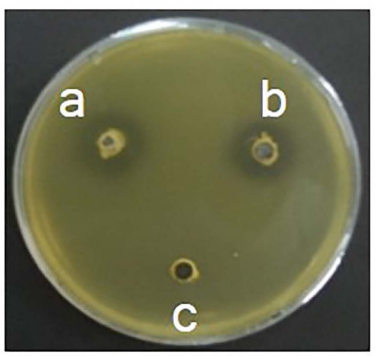

XcCM5

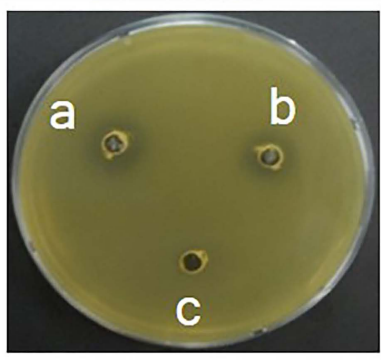

XccM8

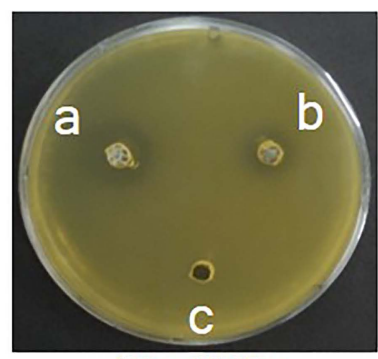

XccW3

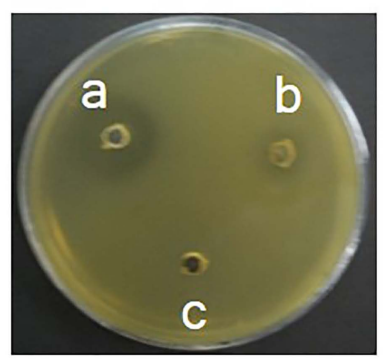

XccM6

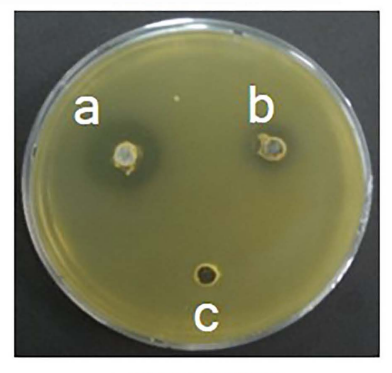

XccM9
Fig. 3. Antagonistic activity of ethyl acetate extracts of endophytic bacteria against Xanthomonas citri subsp. citri $(X c c \mathrm{~W} 1-X c c \mathrm{~W} 3$ [wild-type strains] and XccM4-XccM9 [streptomycin-resistant mutant type strains]) determined by well diffusion assay. a, TbL-22 (Bacillus thuringiensis); b, TbL-26 (B. thuringiensis); c, 5\% dimethyl sulfoxide control.
Determination of MIC and MBC. Since the extract of TbL-22 had the highest antagonistic activity against all $X c c$, it was selected for the determination of MIC and MBC. The values of MIC and MBC for the ethyl acetate extract of TbL-22 ranged from 0.625 to $5.00 \mathrm{mg} / \mathrm{ml}$ and

Table 5. Evaluation of MIC and MBC of ethyl acetate extract of endophytic bacterium Bacillus thuringiensis TbL-22 against Xanthomonas citri subsp. citri $(X c c)$

\begin{tabular}{ccc}
\hline$X c c$ strains & $\mathrm{MIC}(\mathrm{mg} / \mathrm{ml})$ & $\mathrm{MBC}(\mathrm{mg} / \mathrm{ml})$ \\
\hline$X c c \mathrm{~W} 1$ & 5.000 & $>5.00$ \\
$X c c \mathrm{~W} 2$ & 0.625 & 1.25 \\
$X c c \mathrm{~W} 3$ & 5.000 & $>5.00$ \\
$X c c \mathrm{M} 4$ & 2.500 & 5.00 \\
$X c c \mathrm{M} 5$ & 5.000 & $>5.00$ \\
$X c c \mathrm{M} 6$ & 5.000 & $>5.00$ \\
$X c c \mathrm{M} 7$ & 5.000 & $>5.00$ \\
$X c c \mathrm{M} 8$ & 5.000 & $>5.00$ \\
$X c c \mathrm{M} 9$ & 1.250 & 2.50 \\
\hline
\end{tabular}

MIC, minimum inhibitory concentration; MBC, minimum bactericidal concentration. from 1.25 to $>5.00 \mathrm{mg} / \mathrm{ml}$, respectively (Table 5). The lowest MIC and MBC values were found for $X c c$ W2 $(0.625$ $\mathrm{mg} / \mathrm{ml}$ and $1.25 \mathrm{mg} / \mathrm{ml}$, respectively) (Table 5).

SEM analysis with the extract of TbL-22. The effects of the ethyl acetate extract of TbL-22 on cell morphology were observed for $X c c \mathrm{~W} 1, X c c \mathrm{M} 4, X c c \mathrm{M} 6$, and $X c c \mathrm{M} 8$ (Fig. 4). $X c c \mathrm{~W} 1$ was selected to represent the wild-type, and $X c c \mathrm{M} 4, X c c \mathrm{M} 6$, and $X c c \mathrm{M} 8$ were selected as representatives of each mutant on the basis of their genotypic classification. All Xcc treated with the ethyl acetate extract presented with ruptured cell surfaces. They were elongated, shrunken, lysed, and swollen. In contrast, the control Xcc cell surfaces were regular, uniform, and smooth (Fig. 4).

In vivo biocontrol efficacy of the antagonistic endophytes. TbL-22 and TbL-26 were tested for in vivo biocontrol efficacy against $X c c$. In the detached leaf assay, all citrus leaves infiltrated with $X c c \mathrm{~W} 2$, TbL-22, and TbL-26 showed disease symptoms. Nevertheless, the infected areas of the leaves infiltrated with TbL-22 and TbL-26 were 


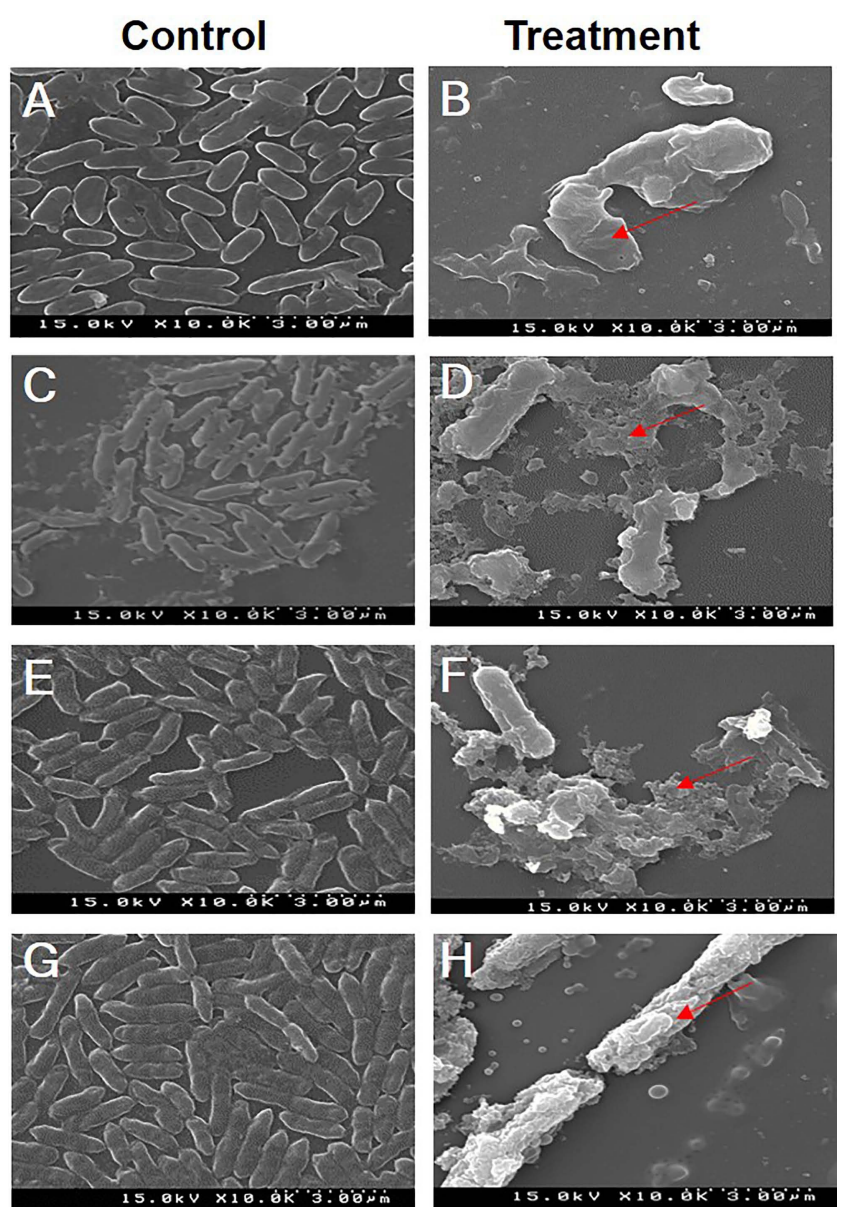

Fig. 4. Photograph of scanning electron microscopy images of Xanthomonas citri subsp. citri $(X c c)$ strains treated with $5 \%$ dimethyl sulfoxide as control (A, C, E, G) and those treated with the ethyl acetate extract of TbL-22 as treatment (B, D, F, H). (A, B) $X c c W 1$. (C, D) XccM4. (E, F) XccM6. (G, H) XccM8. The collapsed and lysed cells are indicated by red arrows.

smaller than those of the leaves treated with $X c c \mathrm{~W} 2$ alone by $64.05 \%$ and $47.76 \%$, respectively (Fig. $5 \mathrm{~A}$ and B). After $7 \mathrm{dpi}, X c c \mathrm{~W} 2$ infiltration alone caused the widest necrotic lesion $(10.68 \pm 1.34 \mathrm{~mm})$, followed by $X c c \mathrm{~W} 2$ with TbL$26(5.58 \pm 0.51 \mathrm{~mm})$ and $X c c \mathrm{~W} 2$ with TbL-22 $(3.84 \pm 0.27$ $\mathrm{mm})$ (Fig. 5C).

Pathogenicity test for the TbL-22 and TbL-26. The lesions that developed on the leaves infiltrated with $\mathrm{XccW} 2$ were usually visible on both surfaces and appeared in the form of water-soaked margins surrounded by yellow rings or haloes (Fig. 6A). Leaves infiltrated with TbL-22 and TbL-26 alone, however, did not display any visible toxic effects or canker symptoms.

\section{Discussion}

Citrus trees are cultivated throughout the tropical and subtropical regions of the world (Webber, 1967). Citrus canker, which is caused by the bacterial pathogen $X c c$, is particularly destructive to citrus. Copper-based bactericides and streptomycin antibiotics have been used in the attempt to control this disease (Behlau et al., 2011; Graham et al., 2008). Nevertheless, they are relatively ineffective on certain Xcc strains (Voloudakis et al., 2005) which have developed resistance to these disease control products (Hyun et al., 2012). Therefore, our aim was to find efficacious alternative citrus canker control measures. EB may serve as powerful canker biocontrol agents.

A total of 134 EB were isolated from the leaves, fruit, seeds, and cones of six different plant species (Table 1). The EB population densities (in cfu/g FW) varied depending on the plant species and tissue (Table 1). Similar findings were published elsewhere (Hallmann et al., 2002; QuadtHallman et al., 1997; Sturz and Nowak, 2000). In the present study, the highest EB densities were found in the leaves of all species tested except for G. biloba. The EB density in its fruit was 33 times higher than that in its leaves (Table 1).

Based on the relative diameters of the inhibition zones they formed on Xcc plates, 18 EB isolates exhibited varying degrees of positive antibacterial activity (Table 2). In addition, solvent extracts of these isolates were evaluated for their antagonistic activity against $X c c \mathrm{~W} 1$ (data not shown). Based on the screening data using the EB and the extracts, the endophytes TbL-22 and TbL-26 were selected for their antibacterial activities against all Xcc strains (Table 3, Fig. 2). Both the endophytes and their ethyl acetate extracts created inhibition zones on $\mathrm{Xcc}$ culture media. Therefore, it may be the metabolites of TbL22 and TbL-26 that are antagonistic to Xcc. Nevertheless, the inhibition zones produced by these two EB differed in size. This discrepancy may be explained by differences in the amount, stability, and diffusion rate of the metabolites secreted by TbL-22 and TbL-26 (Kim et al., 1999). Previous studies reported on the antimicrobial activity of Bacillus spp. like B. subtilis, B. pumilus, B. amyloliquefaciens, B. pasteurii, B. cereus, B. mycoides, and B. sphaericus. These endophytes were isolated from various plants and suppressed the growth of microbial plant pathogens including $X$. oryzae pv. oryzae (Chithrashree et al., 2011; Lin et al., 2001), P. syringae (Bais et al., 2004; Wei et al., 1996), Phytophthora medicaginis (Silo-Suh et al., 1994), Pythium torulosum (Shang et al., 1999), and Botrytis cinerea (Touré et al., 2004). Endophytic B. thuringiensis was used as a 

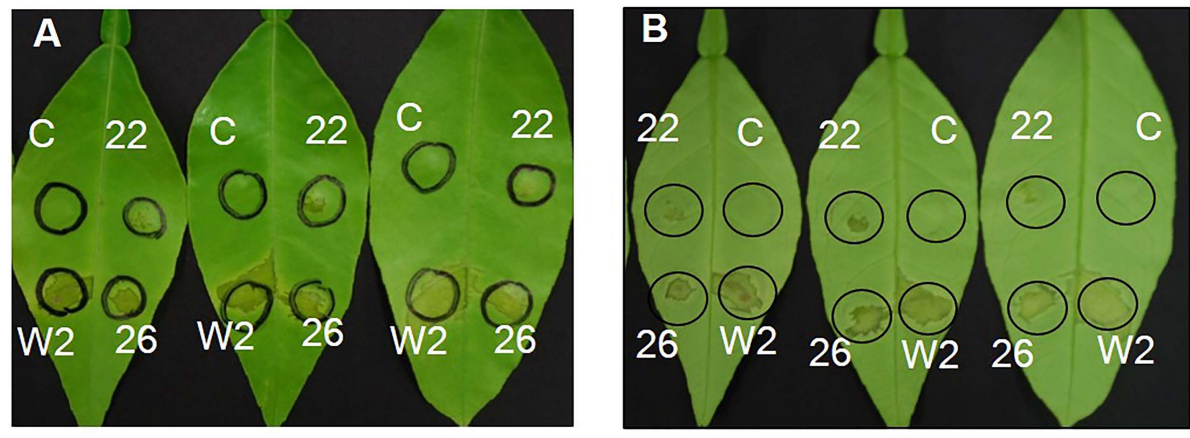

Fig. 5. Disease symptom development at 7 days post-infiltration (dpi) in leaves of Citrus spp. inoculated with Xanthomonas citri subsp. citri (XccW2) and the endophytic bacteria Bacillus

C

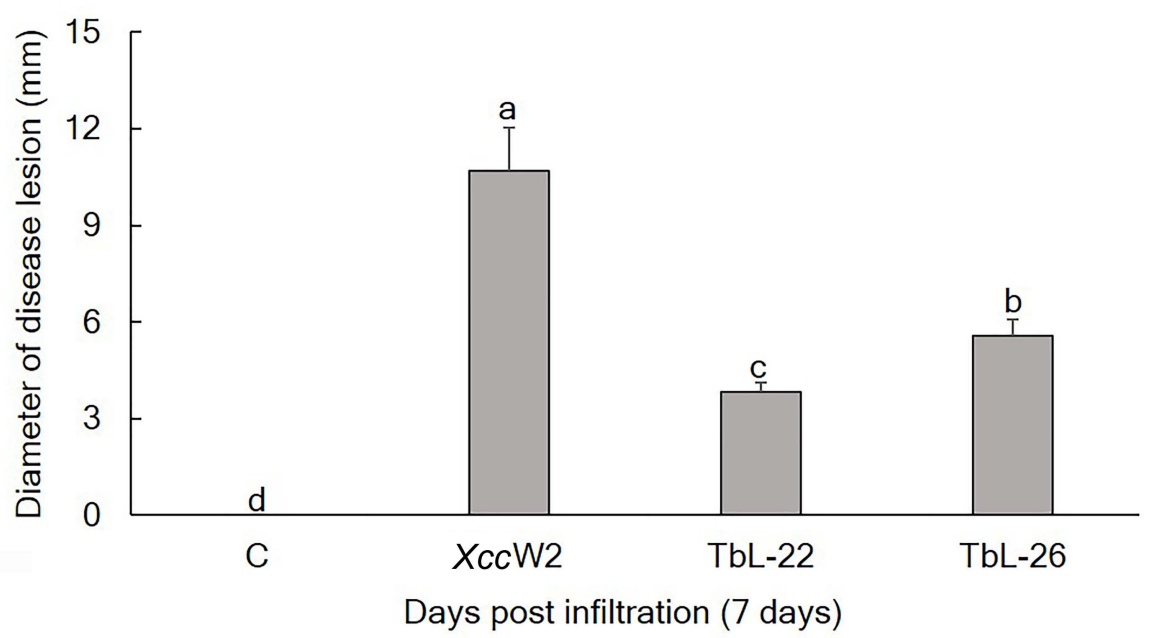
thuringiensis (TbL-22 and TbL-26). In all cases, the leaves were infiltrated with $0.1-\mathrm{ml}$ aliquots of $\mathrm{OD}_{600 \mathrm{~nm}} 0.4 \mathrm{Xcc \textrm {W }} 2$ mixed with sterile distilled water (W2) or $\mathrm{OD}_{600 \mathrm{~nm}} 0.4 \mathrm{Xcc \textrm {W }} 2$ mixed with $\mathrm{OD}_{600 \mathrm{~nm}} 0.4 \mathrm{TbL}-22$ and TbL-26 (22 and 26). (A) Adaxial leaf surface. $C$, control (sterile distilled water); $\mathrm{W} 2, \mathrm{Xcc} \mathrm{W} 2 ; 22$, $X c c \mathrm{~W} 2$ with TbL-22; 26, XccW2 with TbL-26. (B) Abaxial leaf surface. (C) Disease lesion diameter measured $7 \mathrm{dpi}$. The means \pm standard deviation from four independent replicates are presented for each treatment. Means with different letters are significantly different at $P<0.05$ according to Duncan's test.

biocontrol agent against the phytopathogens Ciboria shiraiana, Urocystis agropyri, and Sclerotinia sclerotiorum, and against insects such as silkworms (Bombyx mori) (De Goes et al., 2012; Roh et al., 2007; Schnepf et al., 1998; Sultana and Kim, 2016; Tao et al., 2014; Zhou et al., 2008). $B$. thuringiensis is a Gram-positive, soil-borne bacterium. It has been widely used as a biocontrol agent and bioinsecti- cide (Chattopadhyay et al., 2004; Jouzani et al., 2017).

The ethyl acetate extract of $B$. thuringiensis TbL-22 exhibited the highest antagonistic activity against all $\mathrm{Xcc}$ (Table 4, Fig. 3). Therefore, it is a promising candidate as a biocontrol agent against the streptomycin-resistant strains XccM4-9 (Hyun et al., 2012). The ethyl acetate extract may have contained potent secondary metabolites which sup-
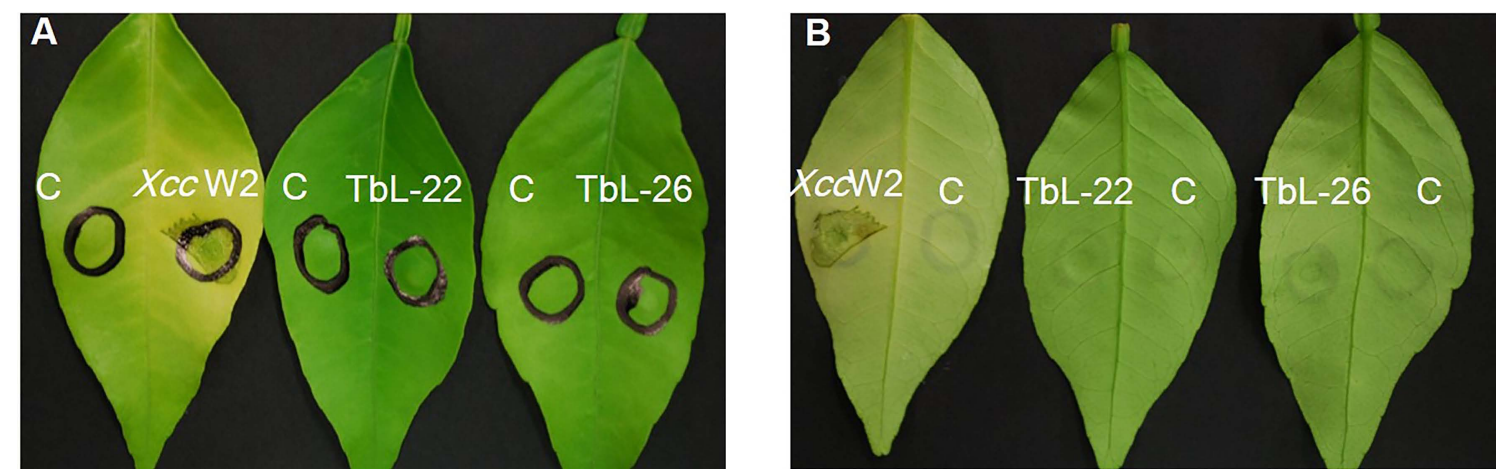

Fig. 6. Pathogenicity test determined by disease symptom development in the leaves of Citrus spp. at 7 days post-infiltration (dpi). Detached fresh leaves were infiltrated with $0.1-\mathrm{ml}$ aliquots of $\mathrm{OD}_{600 \mathrm{~nm}} 0.4$ Xanthomonas citri subsp. citri $(X c c \mathrm{~W} 2)$ and $\mathrm{OD}_{600 \mathrm{~nm}} 0.4$ endophytic bacteria (TbL-22 and TbL-26). (A) Adaxial leaf surface. C, control (sterile distilled water); XccW2, TbL-22, TbL-26. (B) Abaxial leaf surface. 
pressed the growth of $X c c$. Many lipopeptides and fengycin-like substances isolated and purified from $B$. thuringiensis CMB26 were found to be fungicidal, bactericidal, and insecticidal (Kim et al., 2004). B. thuringiensis suppresses plant diseases by producing antimicrobial compounds (Cherif et al., 2008; Dong et al., 2002; Raddadi et al., 2009; Reyes-Ramírez et al., 2004). The TbL-26 extract exerted no antibiotic activity against $X c c \mathrm{~W} 2$ but did suppress both $X c c \mathrm{~W} 1$ and $X c c \mathrm{~W} 3$. This observation suggests that the three pathogen strains may differ in terms of genotype and metabolite susceptibility (Fig. 3). When the Xcc strains were subjected to ethyl acetate extracts of TbL-22, SEM analysis indicated that the cells became irregular, rough, and deformed. They eventually collapsed and lysed (Fig. 4). Similar morphological deformities have been observed in $X$. campestris pv. glycine and Pythium myriotylum treated with the metabolites of endophytic Actinomycetes spp. and Fusarium spp. (Keerthi et al., 2016; Mingma et al., 2014).

EB isolates are known for their beneficial relationships with host plants and their antagonistic activity against plant pathogens (Rosenblueth and Martínez-Romero, 2006). The biocontrol approach is an eco-friendly alternative to chemical pest control products for the suppression of plant diseases. Both in vivo and in vitro tests with $\mathrm{EB}$ and/or their extracts can be used to screen for efficacy. Detached citrus leaves infiltrated with $X c c \mathrm{~W} 2$, TbL-22, and TbL-26 showed significantly reduced disease symptoms in comparison to $X c c \mathrm{~W} 2$ alone infected leaves (Fig. 5), but the two EB did not induce any disease symptoms themselves (Fig. 6). Reductions in citrus canker severity and incidence were also reported for citrus species treated with the Bacillus strains WG6-14 and TKS1-1 and with B. subtilis (S12) (Das et al., 2014; Huang et al., 2012). B. subtilis, $B$. amyloliquefaciens, $B$. pumilus, B. mycoides, B. pasteurii, and $B$. cereus induce plant disease resistance and are commercially available as biocontrol agents (Kloepper et al., 2004; Nam et al., 2016).

In summary, the endophytic Bacillus thuringiensis strains TbL-22 and TbL-26 were determined to be prospective antagonists against both wild-type and streptomycin-resistant $X c c$. Both EB were highly active against Xcc, but TbL-22 was the more potent antibacterial and may serve either as a biocontrol agent or a source of biocontrol compounds. The purification and identification of the antimicrobial metabolites of TbL-22 will be necessary in order to formulate them for agricultural applications. Further in vitro and in vivo research with TbL-22 and/or its extracts may help develop sustainable control measures which could replace the synthetic agrochemicals currently being used to manage Xcc.

\section{Acknowledgments}

This work was supported by a grant from Yeungnam University, Gyeongsan, Korea.

\section{References}

Backman, P. A. and Sikora, R. A. 2008. Endophytes: an emerging tool for biological control. Biol. Control 46:1-3.

Bais, H. P., Fall, R. and Vivanco, J. M. 2004. Biocontrol of Bacillus subtilis against infection of Arabidopsis roots by Pseudomonas syringae is facilitated by biofilm formation and surfactin production. Plant Physiol. 134:307-319.

Bajpai, V. K., Al-Reza, S. M., Choi, U. K., Lee, J. H. and Kang, S. C. 2009. Chemical composition, antibacterial and antioxidant activities of leaf essential oil and extracts of Metasequoia glyptostroboides Miki ex Hu. Food Chem. Toxicol. 47:18761883.

Behlau, F., Canteros, B. I., Minsavage, G. V., Jones, J. B. and Graham, J. H. 2011. Molecular characterization of copper resistance genes from Xanthomonas citri subsp. citri and Xanthomonas alfalfae subsp. citrumelonis. Appl. Environ. Microbiol. 77:4089-4096.

Berg, G., Eberl, L. and Hartmann, A. 2005. The rhizosphere as a reservoir for opportunistic human pathogenic bacteria. Environ. Microbiol. 7:1673-1685.

Brown, A. E. and Soepena, H. 1994. Pathogenicity of Colletotrichum acutatum and C. gloeosporioides on Hevea spp. Mycol. Res. 98:264-266.

Carter, A. P., Clemons, W. M., Brodersen, D. E., Morgan-Warren, R. J., Wimberly, B. T. and Ramakrishnan, V. 2000. Functional insights from the structure of the $30 \mathrm{~S}$ ribosomal subunit and its interaction with antibiotics. Nature 407:340-348.

Chattopadhyay, A., Bhatnagar, N. B. and Bhatnagar, R. 2004. Bacterial insecticidal toxins. Crit. Rev. Microbiol. 30:33-54.

Chen, C., Bauske, E. M., Musson, G., Rodriguezkabana, R. and Kloepper, J. W. 1995. Biological control of Fusarium wilt on cotton by use of endophytric bacteria. Biol. Control 5:83-91.

Cherif, A., Rezgui, W., Raddadi, N., Daffonchio, D. and Boudabous, A. 2008. Characterization and partial purification of entomocin 110, a newly identified bacteriocin from Bacillus thuringiensis subsp. entomocidus HD110. Microbiol. Res. 163:684-692.

Chithrashree, Udayashankar, A. C., Chandra Nayaka, S., Reddy, M. S. and Srinivas, C. 2011. Plant growth-promoting rhizobacteria mediate induced systemic resistance in rice against bacterial leaf blight caused by Xanthomonas oryzae pv. oryzae. Biol. Control 59:114-122.

Das, A. K. and Singh, S. 1999. Management of bacterial canker in acid lime. Intensive Agric. 36:28-29.

Das, A. K. 2003. Citrus canker: a review. J. Appl. Hortic. 5:52-60.

Das, A. K. and Singh, S. 2000. Management of acid lime canker by using chemicals with compatible cultural practices. In: $\mathrm{Hi}$ tech Citrus Management: Proceedings of the International 
Symposium Citriculture, eds. by S. P. Ghosh and S. Singh, pp. 1054-1056. Indian Society of Citriculture and National Research Centre for Citrus, Nagpur, India.

Das, A. K. and Singh, S. 2001. Managing citrus bacterial diseases in the state of Maharashtra. Indian Hortic. 46:11-13.

Das, R., Mondal, B., Mondal, P., Khatua, D. C. and Mukherjee, N. 2014. Biological management of citrus canker on acid lime through Bacillus subtilis (S-12) in West Bengal, India. J. Biopest. 7:38-41.

De Goes, K. C. G. P., de Castro Fisher, M. L., Cattelan, A. J., Nogueira, M. A., de Carvalho, C. G. P. and de Oliveira, A. L. M. 2012. Biochemical and molecular characterization of high population density bacteria isolated from sunflower. J. Microbiol. Biotechnol. 22:437-447.

De Oliveira Costa, L. E., de Queiroz, M. V., Borges, A. C., de Moraes, C. A. and de Araújo, E. F. 2012. Isolation and characterization of endophytic bacteria isolated from the leaves of the common bean (Phaseolus vulgaris). Braz. J. Microbiol. 43:1562-1575.

Dong, Y.-H., Gusti, A. R., Zhang, Q., Xu, J.-L. and Zhang, L.-H. 2002. Identification of quorum-quenching $N$-acyl homoserine lactonases from Bacillus species. Appl. Environ. Microbiol. 68:1754-1759.

Gottwald, T. R., Hughes, G., Graham, J. H., Sun, X. and Riley, T. 2001. The citrus canker epidemic in Florida: the scientific basis of regulatory eradication policy for an invasive species. Phytopathology 91:30-34.

Graham, J. H., Leite, R. P., Yonce, H. D. and Myers, M. 2008. Streptomycin controls citrus canker on sweet orange in Brazil and reduces risk of copper burn on grapefruit in Florida. Proc. Fla. State Hortic. Soc. 121:118-123.

Hallmann, J., Quadt-Hallmann, A., Miller, W. G., Sikora, R. A. and Lindow, S. E. 2002. Endophytic colonization of plants by the biocontrol agent Rhizobium etli G12 in relation to Meloidogyne incognita infection. Phytopathology 91:415422.

Huang, T.-P., Tzeng, D. D.-S., Wong, A. C. L., Chen, C.-H., Lu, K.-M., Lee, Y.-H., Huang, W.-D., Hwang, B.-F. and Tzeng, K.-C. 2012. DNA polymorphisms and biocontrol of Bacillus antagonistic to citrus bacterial canker with indication of the interference of phyllosphere biofilms. PLoS ONE 7:e42124.

Hyun, J.-W., Kim, H.-J., Yi, P.-H., Hwang, R.-Y. and Park, E.-W. 2012. Mode of action of streptomycin resistance in the citrus canker pathogen (Xanthomonas smithii subsp. citri) in Jeju Island. Plant Pathol. J. 28:207-211.

Jalan, N., Kumar, D., Yu, F., Jones, J. B., Graham, J. H. and Wang, N. 2013. Complete genome sequence of Xanthomonas citri subsp. citri strain Aw12879, a restricted-host-range citrus canker-causing bacterium. Genome Announc. 1:e00235-13.

Jouzani, G. S., Valijanian, E. and Sharafi, R. 2017. Bacillus thuringiensis: a successful insecticide with new environmental features and tidings. Appl. Microbiol. Biotechnol. 101:2691-2711.

Keerthi, D., Nair, R. A. and Prasath, D. 2016. Molecular phyloge- netics and anti-pythium activity of endophytes from rhizomes of wild ginger congener, Zingiber zerumbet Smith. World J. Microbiol. Biotechnol. 32:41.

Kim, B. S., Moon, S. S. and Hwang, B. K. 1999. Isolation, identification and antifungal activity of a macrolide antibiotic, oligomycin A, produced by Streptomyces libani. Can. J. Bot. 77:850-858.

Kim, P. I., Bai, H., Bai, D., Chae, H., Chung, S., Kim, Y., Park, R. and Chi, Y.-T. 2004. Purification and characterization of a lipopeptide produced by Bacillus thuringiensis CMB26. J. Appl. Microbiol. 97:942-949.

Kloepper, J. W. and Beauchamp, C. J. 1992. A review of issues related to measuring colonization of plant roots by bacteria. Can. J. Microbiol. 38:1219-1232.

Kloepper, J. W., Ryu, C. M. and Zhang, S. 2004. Induced systemic resistance and promotion of plant growth by Bacillus spp. Phytopathology 94:1259-1266.

Li, H.-Y., Wei, D.-Q., Shen, M. and Zhou, Z.-P. 2012. Endophytes and their role in phytoremediation. Fungal Divers. 54:11-18.

Lin, D., Qu, L. J., Gu, H. and Chen, Z. 2001. A 3.1-kb genomic fragment of Bacillus subtilis encodes the protein inhibiting growth of Xanthomonas oryzae pv. oryzae. J. Appl. Microbiol. 91:1044-1050.

Liu, Y. Q., Heying, E. and Tanumihardjo, S. A. 2012. History, global distribution, and nutritional importance of citrus fruits. Compr. Rev. Food Sci. Food Saf. 11:530-545.

Martínez-Medina, A., Fernández, I., Sánchez-Guzmán, M. J., Jung, S. C., Pascual, J. A. and Pozo, M. J. 2013. Deciphering the hormonal signaling network behind the systemic resistance induced by Trichoderma harzianum in tomato. Front. Plant Sci. 4:206.

McManus, P. S., Stockwell, V. O., Sundin, G. W. and Jones, A. L. 2002. Antibiotic use in plant agriculture. Annu. Rev. Phytopathol. 40:443-465.

Mingma, R., Pathom-aree, W., Trakulnaleamsai, S., Thamchaipenet, A. and Duangmal, K. 2014. Isolation of rhizospheric and roots endophytic actinomycetes from Leguminosae plant and their activities to inhibit soybean pathogen, Xanthomonas campestris pv. glycine. World J. Microbiol. Biotechnol. 30:271-280.

Nam, H.-S., Yang, H.-J., Oh, B. J., Anderson, A. J. and Kim, Y. C. 2016. Biological control potential of Bacillus amyloliquefaciens KB3 isolated from the feces of Allomyrina dichotoma larvae. Plant Pathol. J. 32:273-280.

Patra, J. K., Das, G. and Baek, K.-H. 2015. Antibacterial mechanism of the action of Enteromorpha linza L. essential oil against Escherichia coli and Salmonella typhimurium. Bot. Stud. 56:13.

Paul, D. K. and Shaha, R. K. 2004. Nutrients, vitamins and minerals content in common citrus fruits in the northern region of Bangladesh. Pak. J. Biol. Sci. 7:238-242.

Quadt-Hallman, A., Kloepper, J. W. and Benhamou, N. 1997. Bacterial endophytes in cotton: mechanisms of entering the plant. Can. J. Microbiol. 43:557-582. 
Quispel, A. 1992. A search for signals in endophytic microorganisms. In: Molecular signals in plant-microbe communications, ed. by D. P. S. Verma, pp 471-490. CRC Press, Boca Raton, FL.

Raddadi, N., Belaouis, A., Tamagnini, I., Hansen, B. M., Hendriksen, N. B., Boudabous, A., Cherif, A. and Daffonchio, D. 2009. Characterization of polyvalent and safe Bacillus thuringiensis strains with potential use for biocontrol. J. Basic. Microbiol. 49:293-303.

Ramful, D., Bahorun, T., Bourdon, E., Tarnus, E. and Aruoma, O. I. 2010. Bioactive phenolics and antioxidant propensity of flavedo extracts of Mauritian citrus fruits: potential prophylactic ingredients for functional foods application. Toxicology 278:75-87.

Reyes-Ramírez, A., Escudero-Abarca, B. I., Aguilar-Uscanga, G., Hayward-Jones, P. M. and Barboza-Corona, J. E. 2004. Antifungal activity of Bacillus thuringiensis chitinase and its potential for the biocontrol of phytopathogenic fungi in soybean seeds. J. Food Sci. 69:M131-M134.

Roh, E., Lee, S., Lee, Y., Ra, D., Choi, J., Moon, E. and Heu, S. 2009. Diverse antibacterial activity of Pectobacterium carotovorum subsp. carotovorum isolated in Korea. J. Microbiol. Biotechnol. 19:42-50.

Roh, J. Y., Choi, J. Y., Li, M. S., Jin, B. R. and Je, Y. H. 2007. Bacillus thuringiensis as a specific, safe, and effective tool for insect pest control. J. Microbiol. Biotechnol. 17:547-559.

Rosenblueth, M. and Martínez-Romero, E. 2006. Bacterial endophytes and their interactions with hosts. Mol. Plant Microbe Interact. 19:827-837.

Schnepf, E., Crickmore, N., Van Rie, J., Lereclus, D., Baum, J., Feitelson, J., Zeigler, D. R. and Dean, D. H. 1998. Bacillus thuringiensis and its pesticidal crystal proteins. Microbiol. Mol. Biol. Rev. 62:775-806.

Shang, H., Chen, J., Handelsman, J. and Goodman, R. M. 1999. Behavior of Pythium torulosum zoospores during their interaction with tobacco roots and Bacillus cereus. Curr. Microbiol. 38:199-204.

Silo-Suh, L. A., Lethbridge, B. J., Raffel, S. J., He, H., Clardy, J. and Handelsman, J. 1994. Biological activities of two fungistatic antibiotics produced by Bacillus cereus UW85. Appl. Environ. Microbiol. 60:2023-2030.

Sturz, A. V. and Nowak, J. 2000. Endophytic communities of rhizobacteria and the strategies required creating yield enhancing associations with crops. Appl. Soil Ecol. 15:183-190.
Sultana, R. and Kim, K. 2016. Bacillus thuringiensis C25 suppresses popcorn disease caused by Ciboria shiraiana in mulberry (Morus australis L.). Biocontrol Sci. Technol. 26:145162.

Susilowati, R., Sabdono, A. and Widowati, I. 2015. Isolation and characterization of bacteria associated with brown algae Sargassum spp. from Panjang Island and their antibacterial activities. Proc. Environ. Sci. 23:240-246.

Tamura, K., Stecher, G., Peterson, D., Filipski, A. and Kumar, S. 2013. MEGA6: molecular evolutionary genetic analysis version 6.0. Mol. Biol. Evol. 30:2725-2729.

Tan, X., Huang, S., Ren, J., Yan, W. and Cen, Z. 2007. Characterization of an endophytic bacterium strain Bc51 suppressing citrus canker. Acta Phytopathol. Sin. 37:9-17.

Tao, A., Pang, F., Huang, S., Yu, G., Li, B. and Wang, T. 2014. Characterization of endophytic Bacillus thuringiensis strains isolated from wheat plants as biocontrol agents against wheat flag smut. Biocontrol Sci. Technol. 24:901-924.

Touré, Y., Ongena, M., Jacques, P., Guiro, A. and Thonart, P. 2004. Role of lipopeptides produced by Bacillus subtilis GA1 in the reduction of grey mould disease caused by Botrytis cinerea on apple. J. Appl. Microbiol. 96:1151-1160.

Van Loon, L. C., Bakker, P. A. H. M. and Pieterse, C. M. J. 1998. Systemic resistance induced by rhizosphere bacteria. Annu. Rev. Phytopathol. 36:453-483.

Voloudakis, A. E., Reignier, T. M. and Cooksey, D. A. 2005. Regulation of resistance to copper in Xanthomonas axonopodis pv. vesicatoria. Appl. Environ. Microbiol. 71:782-789.

Webber, H. J. 1967. History and development of the Citrus industry. In: The Citrus industry, Vol. I, eds. by W. Reuther, L. D. Batchelor and H. J. Webber, pp. 1-39. University of California Press, Berkely, CA, USA.

Wei, G., Kloepper, J. W. and Tuzun, S. 1996. Induced systemic resistance to cucumber diseases and increased plant growth by plant growth-promoting rhizobacteria under field conditions. Phytopathology 86:221-224.

Yang, H. L., Sun, X. L., Song, W. and Wang, Y. S. 2001. Studies on the rice endophytic bacteria Entetobacter cloacae MR12's identification and its effects of nitrogen fixation and biological control to plant disease. Acta Phytopathol. Sin. 31:92-93.

Zhou, Y., Choi, Y.-L., Sun, M. and Yu, Z. 2008. Novel roles of Bacillus thuringiensis to control plant diseases. Appl. Microbiol. Biotechnol. 80:563-572. 